\title{
Incorporation of nitrogen into rumen bacterial fractions of steers given protein- and urea-containing diets. Ammonia assimilation into intracellular bacterial amino acids
}

\author{
By J.S. BLAKE*, D. N. SALTER AND R. H. SMITH \\ National Institute for Research in Dairying, Shinfield, Reading, Berkshire RG2 $9 A T$
}

(Received 17 November 1982 - Accepted 30 June 1983)

1. Experiments were carried out in vivo to investigate the pathways of ammonia incorporation into rumen bacteria, bacterial fractions and free amino acids within the bacteria.

2. Steers were alternately given two isoenergetic, isonitrogenous diets containing the nitrogen mainly as either urea or decorticated groundnut meal (DCGM). At the end of each period on a given diet, a solution of ${ }^{15} \mathrm{NH}_{4} \mathrm{Cl}$ was infused into the rumen and samples of rumen contents were removed at 2,10,20 and 90 min and 5, 10 and $24 \mathrm{~h}$ afterwards. Concentrations of ammonia and its ${ }^{15} \mathrm{~N}$ enrichment were determined and samples of mixed rumen bacteria were prepared. Bacteria were disrupted ultrasonically and separated into bacterial protein, cell wall and protein-free cell supernatant fractions. Amino acids were separated after hydrolysis and their ${ }^{15} \mathrm{~N}$ contents determined.

3. A rumen fluid circulation pump was developed so that representative samples could be taken at very short time intervals after the introduction of the ${ }^{15} \mathrm{~N}$ label.

4. Rumen $\mathrm{pH}$ changes, rumen fluid dilution rates and patterns of rumen ammonia concentrations were consistent with normal rumen metabolism. Net bacterial synthesis (as calculated from the net outflow of bacteria from the rumen) was significantly $(P<0.05)$ greater with the DCGM diet $(12.4 \mathrm{~g}$ bacterial N/d) than with the urea diet $(9 \cdot 24 \mathrm{~g}$ bacterial $\mathrm{N} / \mathrm{d})$.

5. With both diets the ${ }^{15} \mathrm{~N}$ label rapidly left the rumen ammonia pool and entered the rumen bacteria. Analysis of the bacterial fractions indicated that the label appeared rapidly in the protein-free cell supernatant fraction and more slowly in the bacterial protein and cell wall fractions.

6. With the DCGM diet bacteria apparently utilized intracellular label less efficiently than with the urea diet. The proportion of $\mathrm{N}$ in the protein-free cell supernatant was higher with the DCGM diet, suggesting increased levels of intracellular amino acids and peptides, following extracellular protein degradation.

7. Levels of enrichment of the amino acids alanine and glutamate in the protein-free cell supernatant fraction suggested that the enzymes alanine dehydrogenase $(E C 1.4 .1 .1)$ and glutamate dehydrogenase $(E C 1.4 .1 .2$ and $1.4 .1 .4)$ may be the major enzymes for assimilating ammonia when concentrations of soluble carbohydrate and rumen ammonia are high in the rumen.

8. The high levels of intracellular alanine are discussed with reference to published work on the excretion of alanine by rumen bacteria.

Large amounts of ammonia are produced in the course of protein and non-protein-nitrogen degradation in the rumen (McDonald, 1952; Lewis, 1955; Warner, 1956; Blackburn \& Hobson, 1960; Blackburn \& Hullah, 1974) and ammonia is thought to be the major source of $\mathrm{N}$ for rumen bacteria (Bryant \& Robinson, 1962; Mathison \& Milligan, 1971; Nolan \& Leng, 1972). Of particular importance in the assimilation of ammonia into rumen bacteria are thought to be the enzymes glutamate dehydrogenase (EC 1.4.1.2 and 1.4.1.4) and glutamine synthetase (EC 6.3.1.2) both having been found in rumen bacteria (Joyner \& Baldwin, 1966; Erfle et al. 1977; Wallace \& Henderson, 1978; Jenkinson et al. 1979). It has been suggested that glutamate dehydrogenase plays the major role in ammonia uptake (Allison, 1969; Smith et al. 1978), with glutamine synthetase becoming more important as ammonia concentration in the rumen becomes low (Erfle et al. 1977; Smith et al. 1978; Jenkinson et al. 1979). Other enzymes such as alanine dehydrogenase (EC 1.4.1.1) and asparagine synthetase ( $E C$ 6 .3 .1 .1$)$ have been identified in rumen bacteria (Burchall et al.

* Present address: BOCM Silcock Ltd, Basing View, Basingstoke, Hampshire RG21 2EQ. 
Table 1. Daily intakes $(\mathrm{kg})$ of dietary constituents by steers

\begin{tabular}{lcc}
\hline \hline Diet... & Urea & DCGM \\
Ingredient & & \\
\hline Alkali-treated straw pellets & 1.20 & 1.20 \\
Tapioca & 1.70 & 1.50 \\
Urea & 0.06 & 0.42 \\
Decorticated groundnut meal (DCGM) & 0.024 & - \\
Potassium sulphate & 0.034 & 0.034 \\
Mineral and trace element premix & 15.5 & 15.5 \\
Total nitrogen (g/kg dry weight) & 10.5 & 10.5 \\
Metabolizable energy (MJ/kg dry weight) & \\
\hline \hline
\end{tabular}

* Contained calcium, magnesium, phosphorus, sulphur, iron, sodium chloride, copper, cobalt, manganese and retinol, cholecalciferol, riboflavin and $\alpha$-tocopherol.

1964; Wallace \& Henderson, 1978), but their role remains unclear. Information on the interaction between the proportion and rate of ammonia incorporation and the supply of dietary amino acids and peptides is scarce, although evidence is available which suggests that bacteria deficient in certain amino acids (Pittman et al. 1967) or their carbon skeletons (Bryant, 1973) have reduced growth and hence a reduced utilization of ammonia.

The experiment described here was designed to study the pathways of ammonia incorporation into free bacterial amino acids. To examine whether differences in $\mathrm{N}$ assimilation exist between bacteria grown under differing dietary conditions, $N$ was supplied mainly as ammonia- $\mathrm{N}$ (urea diet) or as a mixture of peptide, amino acid and ammonia- $\mathrm{N}$ derived from protein degradation (decorticated groundnut meal (DCGM) diet).

In a previous study (Salter et al. 1979) the utilization of ${ }^{15} \mathrm{~N}$-labelled urea for the synthesis of rumen bacterial $\mathrm{N}$ compounds in the presence or absence of dietary protein was investigated. It was found that ${ }^{15} \mathrm{NH}_{3}$ formod from the labelled urea was rapidly incorporated into bacterial $\mathrm{N}$ compounds, the most highly-labelled amino acid being glutamate, followed by aspartate and alanine. As whole bacteria had been used no information was obtained on the course of labelling of the free intracellular amino acids on which subsequent protein synthesis depends, and which may serve as sensitive indicators of the effects of different dietary sources of $\mathrm{N}$ on this process.

A preliminary communication of parts of this work has been published (Blake et al. 1981).

EXPERIMENTAL

Animals and diets

Four Friesian steers, about 30 weeks of age, weighing approximately $120-150 \mathrm{~kg}$ and fitted with rumen cannulas $(50.5 \mathrm{~mm}$ internal diameter) were used. Each steer was given each of two diets (Table 1) in turn. Two of the steers received the urea diet first and two the DCGM diet first. The first diet was given for 3 weeks before an experiment was done. On the day of an experiment, a dose of ${ }^{15} \mathrm{NH}_{4} \mathrm{Cl}$ was infused into the rumen and samples of rumen contents taken. The second diet was given on the day following this infusion and after 3 weeks the experiment was repeated. On the morning of an experiment the steers receiving the urea diet were given a slurry containing $(\mathrm{g}): 850$ tapioca, 25 urea, 12 potassium sulphate and 22.5 sodium chloride in 51 water directly into the rumen. For the steers receiving the DCGM diet the slurry contained (g): 750 tapioca, 200 DCGM and $22.5 \mathrm{NaCl}$ in 51 water. No straw pellets were included in these infusions. After $1 \mathrm{~h}$ a solution containing $9.00 \mathrm{~g}^{15} \mathrm{NH}_{4} \mathrm{Cl}(30 \cdot 8 \%$; Prochem, British Oxygen $\mathrm{Co}$, London) and $25 \mathrm{~g}$ polyethylene glycol 
(molecular weight 4000; PEG) dissolved in $200 \mathrm{ml}$ saline $(9 \mathrm{~g} \mathrm{NaCl} / 1)$ was also infused into the rumen via the cannula. No further feed was given until after the $24 \mathrm{~h}$ sample and water was not offered throughout the $24 \mathrm{~h}$ except for $15 \mathrm{~min}$ after the $10 \mathrm{~h}$ sample.

\section{Collection of rumen contents}

Samples of rumen fluid (approximately $700 \mathrm{ml}$ ) were collected using a specially developed rumen fluid circulation pump. This pump allowed both rapid mixing of infusion solutions into rumen fluid and representative samples of rumen fluid to be taken. A description of the mode of action of the pump is given in the relevant section of the present paper. Rumen samples were collected just before the ${ }^{15} \mathrm{~N}$ infusion ( 0 min sample) and then at $2,10,30$ and $90 \mathrm{~min}$ and 5,10 and $24 \mathrm{~h}$ after the introduction of the ${ }^{15} \mathrm{~N}$ label. The rumen fluid circulation pump ran continuously for the first $30 \mathrm{~min}$ of the experiment and at least $10 \mathrm{~min}$ before each of the later samples. After collection, the samples were rapidly cooled in an ice-salt-water bath at $-10^{\circ}$ and then stored at $1^{\circ}$ until further processing. Care was taken not to freeze the sample to prevent disruption of bacterial cells.

\section{Preparation, disruption and fractionation of rumen bacteria}

Separation of rumen bacteria from the rumen contents was carried out using a differential centrifugation technique as described by Salter $e t$ al. 1979. The end product of this technique was a bacteria suspension containing about $50 \mathrm{~g}$ dry matter $/ \mathrm{kg}$.

Rumen bacteria were disrupted using ultrasonic waves and glass ballotini in the following procedure: approximately $35-40 \mathrm{~g}$ of the bacterial suspension were weighed into a $50 \mathrm{ml}$ pyrex beaker and glass ballotini $(0.2 \mathrm{~mm}$ diameter solid glass balls, grade no. 12 ; Jencons Scientific Ltd, Leighton Buzzard, Beds) equal to about one-third of the volume of bacteria added. The beaker was positioned in the centre of an ice-salt-water bath at $-10^{\circ}$ and the contents of the beaker stirred gently with a thermometer until the temperature reached $4^{\circ}$. An ultrasonic probe (Soniprobe; Dawe Instruments Ltd, London) was placed in the beaker with the tip 10-20 mm below the surface of the liquid. The probe was turned on to full power $(5 \mathrm{amp})$ for $5 \mathrm{~min}$, followed by a $3 \mathrm{~min}$ break to allow the bacteria to cool again to $4^{\circ}$. The cycle was repeated twice, making a total disruption time of $15 \mathrm{~min}$. This procedure ensured at least $95 \%$ disruption of the bacteria and kept the temperature of the suspension below $15^{\circ}$.

The suspension of disrupted bacteria was passed through a sintered glass filter (Sinter-Glass grade no. 1; Gallenkamp Ltd, London) to remove the glass ballotini. These were washed twice with approximately 20 -ml portions of water and the washings bulked with the filtrate. This filtered suspension was centrifuged at $30000 \mathrm{~g}$ for $15 \mathrm{~min}$ at a temperature of $1^{\circ}$ (MSE High Speed 18 centrifuge; Measuring \& Scientific Equipment Ltd, Crawley, Sussex) to remove the cell wall and remaining whole cells, which were washed twice with water, freeze-dried and stored (cell wall fraction). The washings were bulked with the supernatant from the high speed spin and $1.5 \mathrm{vol}$. of sulphosalicylic acid solution $\left(36 \mathrm{~g} 5^{\prime}\right.$-sulphosalicylic acid (SSA)/1) added to precipitate the proteins. After leaving overnight at $4^{\circ}$, the solution was centrifuged at $30000 \mathrm{~g}$ for $15 \mathrm{~min}$ at a temperature of $1^{\circ}$. The residue was washed twice with a dilute solution of SSA (3.6 g SSA/1), freeze dried and stored (precipitated-protein fraction). The supernatant fraction plus the washings were reduced to dryness under reduced pressure at $40^{\circ}$, redissolved in $5 \mathrm{ml}$ of water and the $\mathrm{pH}$ adjusted to 2.5 with $10 \mathrm{M}$-sodium hydroxide. The SSA which precipitated as the sodium salt, was removed by filtering through Whatman no. 1 filter paper, and washed with a small amount of water. The filtrate was reduced to dryness under reduced pressure at $40^{\circ}$, dissolved in $4 \mathrm{ml} 0.2 \mathrm{M}$-citrate buffer ( $\mathrm{pH}$ 2.2), passed through a $0.45 \mu \mathrm{m}$ membrane filter (type HAW02500, Millipore (UK) Ltd, Millipore House, London) and made up to $5 \mathrm{ml}$ with $0 \cdot 2 \mathrm{M}$-citrate buffer (protein-free cell supernatant fraction). 

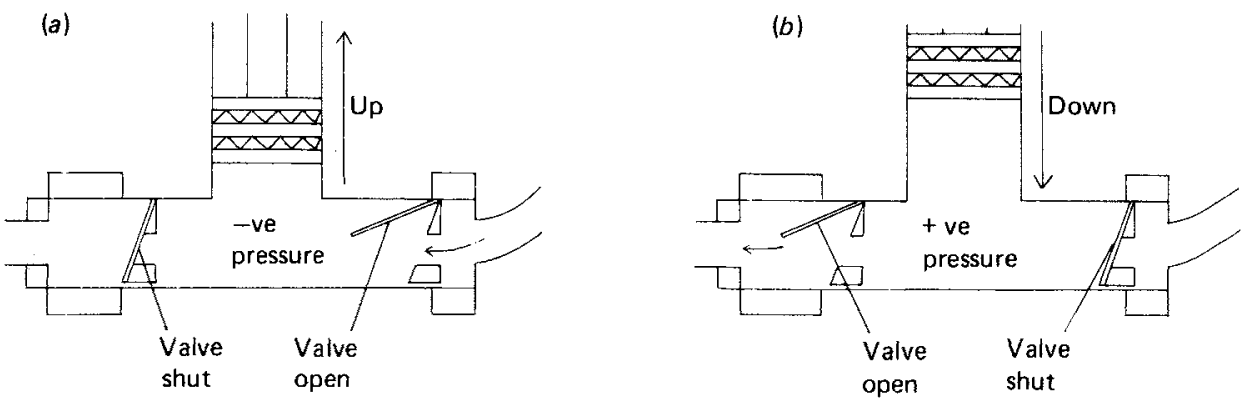

Fig. 1. Mode of action of the rumen contents circulation pump, showing material being 'sucked' into the chamber of the pump $(a)$ and being forced back into the rumen $(b)$.

\section{Development of the rumen fluid circulation pump}

The pump was based on an idea used by Sutherland et al. (1962), but with an improved design and different materials. The basic principle was that of changing pressures in a large chamber at either ends of which were placed one way rubber 'flap' valves. The operation of the pump is shown in Fig. 1. As the piston moves up (Fig. 1 $a$ ) it creates a negative pressure in the chamber, opening the inlet valve, closing the outlet valve and sucking rumen contents into the pump. When the piston moves down (Fig. $1 b$ ) a positive pressure is created in the chamber, closing the inlet valve and forcing the contents of the chamber through the now open outlet valve and back into the rumen. This enabled pumping of complete rumen contents including the short staple straw present and had the capacity to pump this material at a fast rate (about 71 rumen contents/min). Despite its fast action and associated noise, none of the animals used in this experiment showed any concern about the pump, and appeared not to be stressed by its action. The pump was tested by infusing PEG into the rumen of steers and taking rumen samples at 2 -min intervals. From $\log _{10}$ PEG concentration $v$. time the point at which values became virtually constant was taken as the time at which the PEG was completely mixed with rumen contents. An example is given in Fig. 2. The final version of the pump could achieve complete mixing in $8 \mathrm{~min}$ although even at $2 \mathrm{~min}$ the PEG appeared to be $90 \%$ mixed.

\section{Analytical procedures}

Measurement of the ammonia concentration of rumen fluid and the estimation of bacterial $\mathrm{N}$ synthesis are described by Salter et al. (1979). PEG was determined using the method described by Smith (1962), except that $20 \mathrm{~min}$ was allowed for the development of the turbidity. Dry weight of samples $(4 \mathrm{~g})$ was determined after drying at $105^{\circ}$ for $12 \mathrm{~h}$.

\section{Determination of total $N$ in bacteria and bacterial fractions}

Samples of suspensions of rumen bacteria $(1 \mathrm{~g})$, samples of the cell wall and precipitatedprotein fractions $(40 \mathrm{mg})$ and portions of the protein-free cell supernatant fraction $(0 \cdot 1 \mathrm{ml})$ were digested and analysed for total $\mathrm{N}$ as previously described for digesta samples (Salter \& Smith, 1977).

Analysis of amino acids in the bacterial fractions. Quantitative amino acid analysis of samples of cell wall and precipitated-protein fractions $(36 \mathrm{mg})$, hydrolysed with constant boiling hydrochloric acid in sealed tubes in vacuo, was carried out by ion-exchange chromatography, using an LKB amino acid analyser (Model No. 4102, LKB Ltd, Cambridge). 


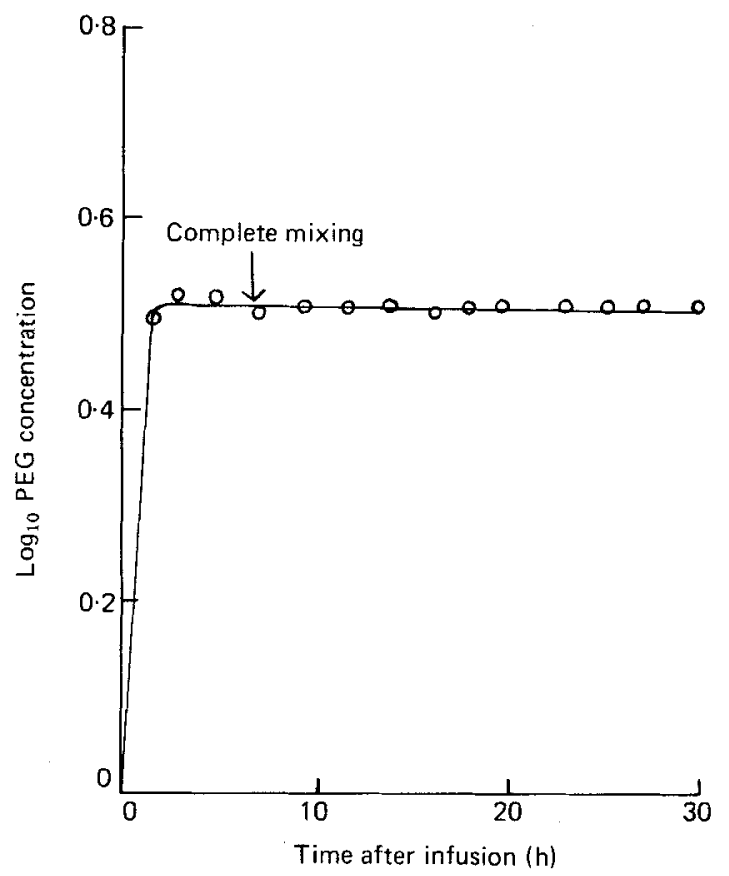

Fig. 2. Example of the capacity of the rumen circulation pump to mix a single infusion of polyethylene glycol with rumen contents.

Portions of the protein-free cell supernatant fractions were diluted with $0 \cdot 2 \mathrm{M}$-lithium citrate buffer ( $\mathrm{pH} 2.2)$ and quantitative amino acid analysis carried out by ion-exchange chromatography with a lithium buffer system (Benson et al. 1967).

Preparative amino acid separation for ${ }^{15} \mathrm{~N}$ analysis. An EEL multichannel automatic amino acid analyser (Evans Electroselenium Ltd, EEL/Corning, Halstead, Essex) was fitted with 9-mm diameter columns and used to prepare amino acids from the remaining portions of the acid hydrolysate (from the cell wall and precipitated-protein fractions) and from the protein-free cell supernatant fraction. The analyser was fitted with a peristaltic pump (Ismatec mp-13; Grant Instruments (Cambridge) Ltd, Barrington, Cambridge) which split the column effluent so that $10 \%$ was returned to the analyser for reaction with ninhydrin and peak identification and $90 \%$ was directed to a fraction collector (Toyo SF 4002; Chem-Lab Instruments Ltd, London). The output from the $570 \mathrm{~nm}$ photoelectric cell in the amino acid analyser was connected to a slave recorder containing an electro-mechanical device (Goulden \& Salter, 1979a) which triggered the fraction collecter at the beginning of each amino acid peak. The preparative flow was delayed by a coil so that a peak appearing on the recorder chart exactly matched the liquid leaving the end of the delay coil. This distance was checked before each preparative separation by injection of a small amount of blue ink into the line just before the stream was split. The appearance of the first drop of ink at the end of the delay coil could then be matched with the appearance of the peak on the chart recorder. The amino acids were identified by their relative positions on the chart paper and in the fraction collector, bulked and evaporated to dryness at $80^{\circ}$.

Measurement of ${ }^{15} \mathrm{~N}$ in bacteria, bacterial fractions and rumen ammonia. Kjeldahl digests prepared as for the total $\mathrm{N}$ determination of rumen bacteria and bacterial fractions were diluted to $10 \mathrm{ml}$ with water, approximately $5 \mathrm{ml}$ transferred to a Markham steam-distillation unit, and $12-15 \mathrm{ml} 10 \mathrm{M}-\mathrm{NaOH}$ solution containing sodium thiosulphate $(25 \mathrm{~g}$ sodium 
thiosulphate/l) was added. Distillate was collected in a $100 \mathrm{ml}$ flask containing $10 \mathrm{ml}$ $0.025 \mathrm{M}-\mathrm{HCl}$ until its volume reached about $60 \mathrm{ml}$. The flask containing the distillate was evaporated to dryness at $80^{\circ}$ and the ammonium chloride so formed stored in a bijou bottle. Measurement of ${ }^{15} \mathrm{~N}$ isotopic abundance in the samples was determined by an automatic ${ }^{15} \mathrm{~N}$ emission spectrometer designed and built at the National Institute for Research in Dairying (Goulden \& Salter, 1979b).

For the determination of ${ }^{15} \mathrm{~N}$ in rumen ammonia, the acid-indicator mixture in the centre well of a Conway unit was replaced with $0.05 \mathrm{M}-\mathrm{HCl}(1 \mathrm{ml})$ and after completion of diffusion of the ammonia, the acid solution containing the labelled ammonium ions was withdrawn, evaporated to dryness and the ${ }^{15} \mathrm{~N}$ determined as described previously.

Measurement of ${ }^{15} \mathrm{~N}$ in separated amino acids from bacterial fractions. These samples contained very small amounts of $\mathrm{N}(30-100 \mu \mathrm{g} \mathrm{N})$, and in a preliminary experiment it was found that when the Markham steam-distillation method was used there was carry-over of ${ }^{15} \mathrm{~N}$ between samples. This was thought to be due to very small amounts of $\mathrm{N}$ being absorbed on to the glass surfaces of the still. The effect was minimal when larger amounts of $\mathrm{N}$ were distilled (e.g. whole bacteria and bacterial fractions) but increased in importance as the amount of $\mathrm{N}$ distilled dropped below $100 \mu \mathrm{g} \mathrm{N}$. To prevent ${ }^{15} \mathrm{~N}$ cross-contamination, $\mathrm{N}$ in amino acid samples was converted to ammonium chloride using the Nessler method of Lloyd-Jones et al. (1977) adapted for use with a Conway microdiffusion technique.

The dried residues from the amino acid preparation system were redissolved in $3 \mathrm{ml}$ concentrated sulphuric acid (Aristar), catalyst added $(1.2 \mathrm{~g}$ potassium sulphate, hydrogen peroxide added dropwise), and the mixture digested (Florence \& Milner, 1979). After completion of digestion and cooling, the digests were transferred to $50 \mathrm{ml}$ plastic centrifuge tubes with water, and to each $4 \mathrm{ml}$ Nessler reagent $(\mathrm{g} / 1 ; 13.5$ mercury iodide, 12.0 potassium iodide) and approximately $12 \mathrm{ml} 10 \mathrm{M}-\mathrm{NaOH}$ added. The amount of $\mathrm{NaOH}$ added varied according to the amount needed to produce the red-brown Nessler complex. The tubes were placed in a water bath at $80^{\circ}$ for $30 \mathrm{~min}$ and then immediately centrifuged at $200 \mathrm{~g}$ for $10 \mathrm{~min}$ at room temperature (MSE Mistral $4 \mathrm{~L}$ centrifuge). The colourless supernatant fraction was discarded and the tubes inverted on paper tissues to drain for at least $10 \mathrm{~min}$, leaving the Nessler complex as a pellet at the bottom of the tube. Ethanolic $\mathrm{HCl}(1 \mathrm{M}-\mathrm{HCl}$ containing $100 \mathrm{ml}$ ethanol/1; $1 \mathrm{ml}$ ) was added to each tube to dissociate the complex and the tube left for $15 \mathrm{~min}$ at room temperature. Finally, $1 \mathrm{ml}$ sodium sulphide solution ( $50 \mathrm{~g}$ sodium sulphide/l) was added to precipitate the mercury and prevent the Nessler complex reforming. This solution was poured into the outer chamber of a Conway unit, ${ }^{15} \mathrm{NH}_{4} \mathrm{Cl}$ prepared and ${ }^{15} \mathrm{~N}$ determined as described for the rumen ammonia.

\section{Statistical analysis}

Measurements, made on all four steers, were analysed at each time point by analysis of variance including a between diet-order term and tests of significance made by the $F$ test. Measurements on bacterial fractions and amino acids were only carried out on two animals and were not analysed statistically.

\section{RESULTS}

Following introduction of tapioca, rumen $\mathrm{pH}$ fell from $7 \cdot 0$ to a minimum value of about $6 \cdot 2,1.5 \mathrm{~h}$ later. The $\mathrm{pH}$ slowly rose to 6.9 during the next $8 \cdot 5 \mathrm{~h}$. Rumen fluid dilution rates were not significantly different between animals or diets, with a mean (SE) of $0.035,(0.007) / \mathrm{h}$. This rate agrees with other published values (Harrison et al. 1975; Cole et al. 1976; Prigge et al. 1978).

Net amounts of bacteria synthesized in the rumen over the $24 \mathrm{~h}$ were estimated from the rumen fluid turnover rates, enrichments of ${ }^{15} \mathrm{~N}$ in the bacteria and rumen fluid non- 
(a)
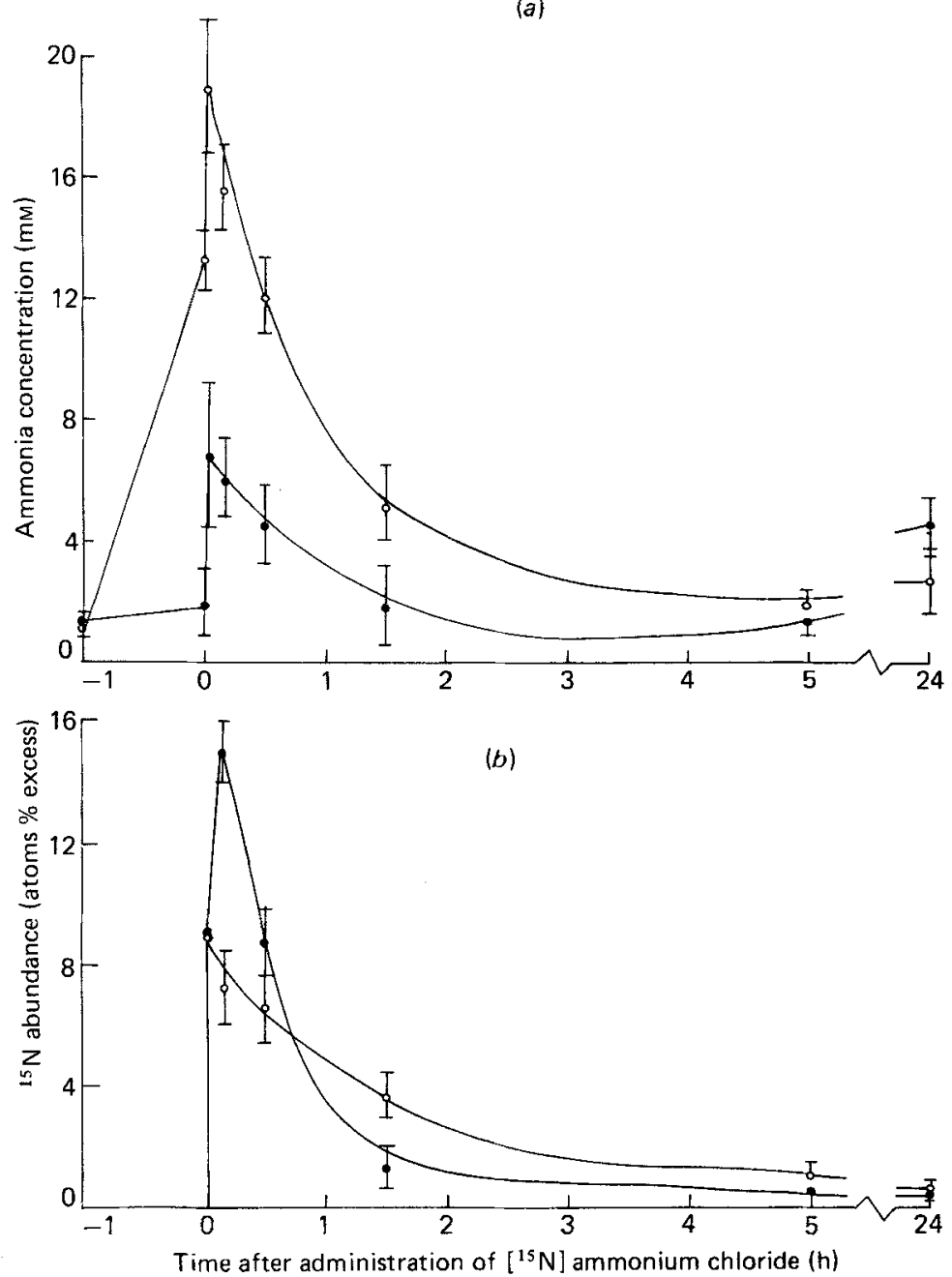

Fig. 3. Variation of $(a)$ concentration and $(b){ }^{15} \mathrm{~N}$ enrichment (atoms \% excess) of rumen ammonia with time-interval after introducing feed slurry (at $-1 \mathrm{~h}$ ) and a dose of ${ }^{15} \mathrm{NH}_{4} \mathrm{Cl}$ (at $0 \mathrm{~h}$ ) into the rumen. (O) Urea diet, ( ) decorticated groundnut meal diet; for details of diets, see Table 1 and p. 770.

ammonia-N, as described by Salter et al. (1979). The calculation depends upon the assumption that (a) rumen volume remained constant, (b) strained rumen contents were representative of digesta flowing from the rumen. Mean (SE) values ( $g$ bacterial $\mathrm{N} / \mathrm{d}$ ) were significantly greater $(P<0.05)$ with the DCGM diet $(12.4(0.67))$ than with the urea diet $(9 \cdot 24(0 \cdot 67))$.

The concentrations of rumen ammonia with the two diets are given in Fig. $3 a$. Prefeeding ammonia concentrations were similar for both diet groups, but after feeding there was a marked increase in the urea-fed group due to rapid hydrolysis of urea and a much smaller increase in the DCGM group owing to slower production of ammonia from protein. Infusion of ${ }^{15} \mathrm{NH}_{4} \mathrm{Cl}$ resulted in further equal increments in total ammonia concentrations in both groups. Ammonia concentrations decreased rapidly, almost returning to prefeeding levels in the DCGM group during the next $3 \mathrm{~h}$, but remained consistently higher in the urea 


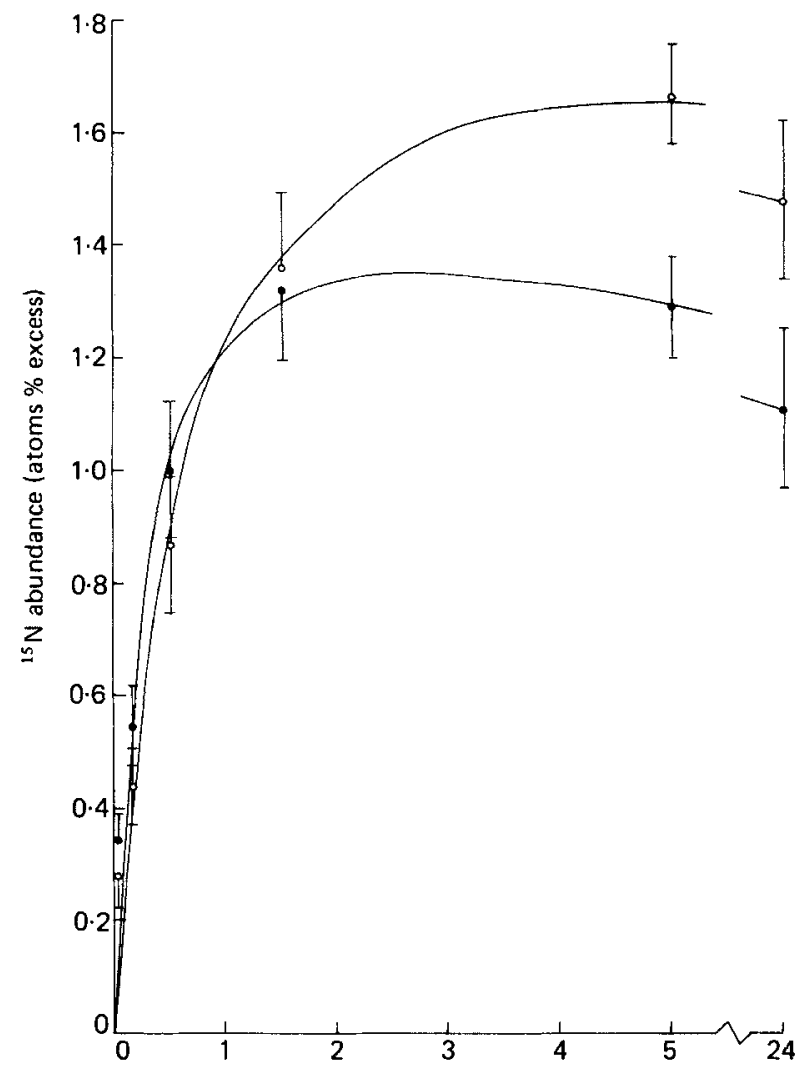

Time after administration of $\left[{ }^{15} \mathrm{~N}\right]$ ammonium chloride $(\mathrm{h})$

Fig. 4. Variations of ${ }^{15} \mathrm{~N}$ enrichment (atoms \% excess) of rumen bacteria with time-interval after administration of ${ }^{15} \mathrm{NH}_{4} \mathrm{Cl}$ into the rumen. (O) Urea diet; (O) decorticated groundnut meal diet; for details of diets, see Table 1 and p. 770.

group. The ${ }^{15} \mathrm{~N}$ enrichment of rumen $\mathrm{NH}_{3}$ is given in Fig. $3 b$. Enrichments were higher initially with the DCGM diet as the pool size was smaller (Fig. $3 a$ ) and dilution of the infused label less. With both diets, the ${ }^{15} \mathrm{~N}$ abundance of rumen ammonia dropped rapidly in the first $90 \mathrm{~min}$ as label left this pool, and the remainder was diluted out by natural abundance ammonia entering from endogenous sources with the urea diet, and from endogenous sources plus protein degradation with the DCGM diet. This explains the more rapid decline of ${ }^{15} \mathrm{~N}$ enrichments of rumen ammonia with the DCGM diet. As ${ }^{15} \mathrm{~N}$ left the rumen ammonia pool it entered the rumen bacteria (Fig. 4). Initially, more label appeared in the bacteria from the steers given the DCGM diet as the enrichment of rumen ammonia available to these bacteria was higher (Fig. $3 b$ ); however, after the 90 min sample, bacteria from the steers given the urea diet became more highly enriched.

The proportions of $\mathbf{N}$ found in the component bacterial fractions showed no clear variation with time, values remaining relatively constant during $5 \mathrm{~h}$, with approximately $60-70 \%$ of the bacterial $\mathrm{N}$ in the precipitated-protein, $10-20 \%$ in the cell wall and $10-25 \%$ in the protein-free cell supernatant fractions. Comparisons between diets of the $\mathrm{N}$ content in the precipitated-protein and cell wall fractions showed a slightly higher proportion of $\mathrm{N}$ for the urea diet, although variations between animals were large. However, approximately twice the proportion of bacterial $\mathrm{N}$ appeared in the protein-free cell supernatant fraction 
(a)

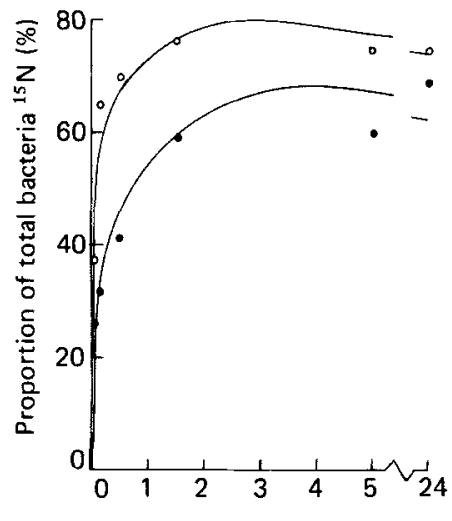

(b)

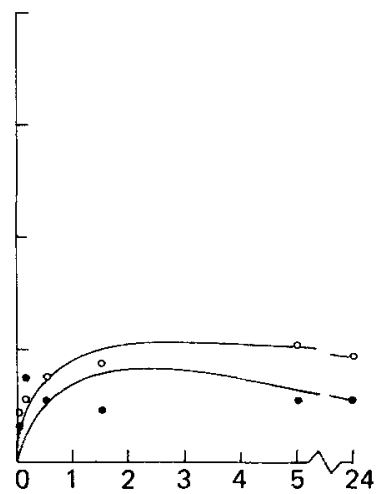

(c)

Time after administration of $\left[{ }^{15} \mathrm{~N}\right]$ ammonium chloride $(\mathrm{h})$

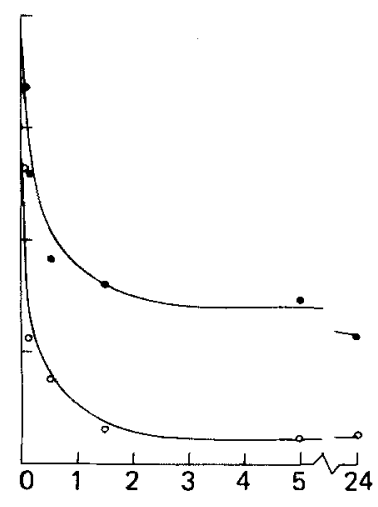

Fig. 5. Variations of the proportions of total bacterial ${ }^{15} \mathrm{~N}$ found in the bacterial fractions $((a)$ protein, (b) cell wall and (c) protein-free cell supernatant fraction) with time after the administration of ${ }^{15} \mathrm{NH}_{4} \mathrm{Cl}$ into the rumen. (O), Urea diet; $(O)$, decorticated groundnut meal diet; for details of diets, see Table 1 and p. 770 .

with the DCGM diet (means 0.11 and 0.24 respectively for urea and DCGM diets). With both diets, there were marked differences in the proportions of bacterial ${ }^{15} \mathrm{~N}$ in the subcellular fractions (Fig. 5) but, with both diets, label rapidly entered the protein-free cell supernatant fraction and then appeared more slowly in the precipitated-protein and cell wall fractions. Clear differences between diets were also apparent, more ${ }^{15} \mathrm{~N}$ appearing in the precipitated-protein and cell wall fractions with the urea diet, but more ${ }^{15} \mathrm{~N}$ remaining in the protein-free cell supernatant fraction with the DCGM diet.

Changes in the concentrations of all free intracellular amino acids followed similar patterns with both diets, with levels reaching a peak soon after the ${ }^{15} \mathrm{NH}_{4} \mathrm{Cl}$ infusion, followed by a steady decline. An example is given for three amino acids from one steer in the DCGM diet (Fig. 6). In spite of these changes and considerable variation between animals (particularly when the DCGM diet was given) the relation between the different amino acids remained essentially the same throughout the experiment. The pattern is demonstrated by the results in Table 2 which show mean values during the first $5 \mathrm{~h}$ after ${ }^{15} \mathrm{NH}_{4} \mathrm{Cl}$ infusion. Certain consistent trends were apparent. The amino acids present in the highest concentrations were alanine, glutamate, glycine and lysine. Very small amounts of glutamine were detected with the urea diet but none with the DCGM diet, and no asparagine was found with either diet. However, as no check was made on the recovery of the amides in the free amino acids fraction these may be regarded as minimum values. The concentration of intracellular ammonia (determined by ion-exchange chromatography) was lower than alanine with the urea diet, but higher with the DCGM diet.

There were marked differences between the ${ }^{15} \mathrm{~N}$ enrichments of the amino acids in the protein-free cell supernatant fraction (Table 3). Values with the DCGM diet were higher than with the urea diet, possibly a consequence of the higher enrichment of rumen ammonia with this diet. Intracellular ammonia was, with both diets, more rapidly labelled, and its enrichment remained generally higher than that of any amino acid, reaching a peak between the 10 and $30 \mathrm{~min}$ samples. Of the amino acids, alanine, glutamate, aspartate and lysine were labelled at a higher rate than any others, the order being alanine $>$ glutamate $>$ lysine $>$ aspartate with the urea diet and alanine $>$ glutamate $>$ aspartate $>$ lysine with 


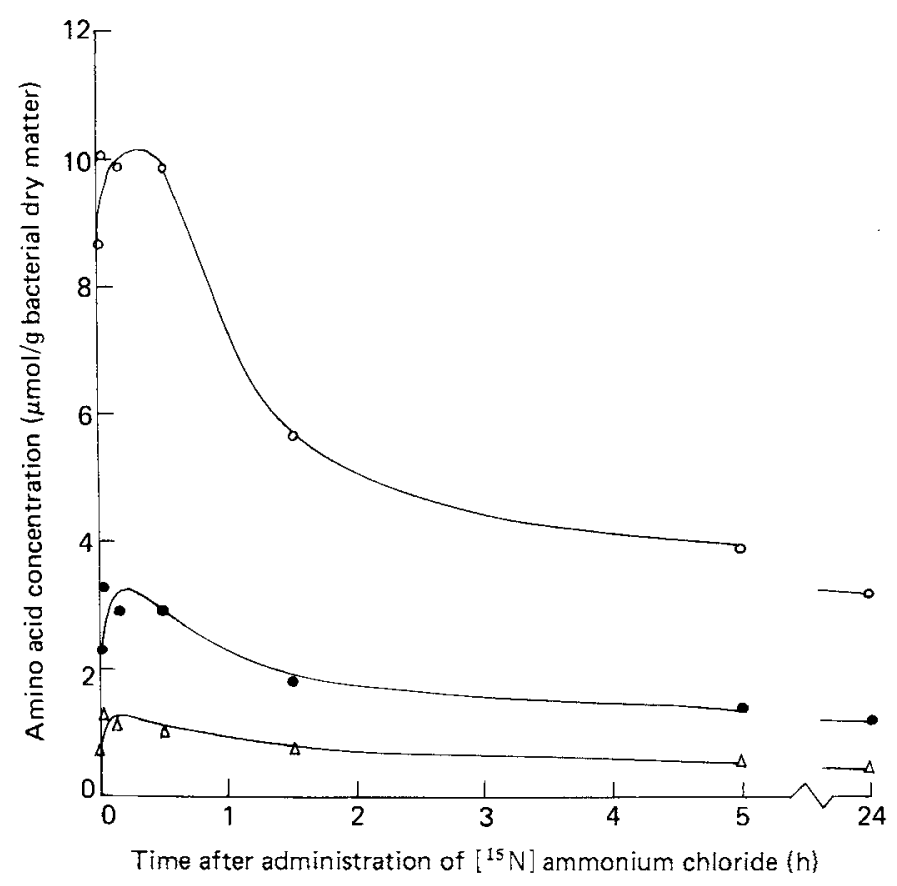

Fig. 6. Variation of concentration ( $\mu \mathrm{mol} / \mathrm{g}$ bacterial dry matter) of free bacterial amino acids with time-interval after administration of ${ }^{15} \mathrm{NH}_{4} \mathrm{Cl}$ into the rumen, for one steer given the decorticated groundnut meal diet. $(\bigcirc)$, Alanine; $(\circlearrowleft)$, leucine; $(\triangle)$, phenylalanine.

the DCGM diet. At no time during the first $30 \mathrm{~min}$, for either diet, was the ${ }^{15} \mathrm{~N}$ enrichment of glutamate higher than that of alanine.

\section{DISCUSSION}

The development of a technique of rapid mixing of whole rumen contents in vivo made it possible to take samples of rumen fluid that were reasonably representative as early as 2 min after the introduction of $\left[{ }^{15} \mathrm{~N}\right]$-labelled ammonium salt. By fractionating the bacteria into cell wall, protein and soluble fractions, it was thus possible to obtain information about the rate of labelling of individual free amino acids in the early stages of ammonia incorporation into the rumen bacteria. Precautions were taken to ensure that the temperature of the cells was kept at $1^{\circ}$ during processing, except for a brief period during cell disruption, and it is unlikely that any significant further metabolism occurred. In a previous study, the incorporation of ${ }^{15} \mathrm{~N}$ from ${ }^{15} \mathrm{~N}$-urea was measured only at intervals from $30 \mathrm{~min}$ after introduction of the label, and without subcellular fractionation (Salter et al. 1979).

In the present study, conditions of labelling differed in some respects from those used earlier; the ${ }^{15} \mathrm{~N}$ was introduced in the form of ammonium chloride $1 \mathrm{~h}$ after the introduction of dietary urea at a time when urea conversion to ammonia was virtually complete. The immediate effect of infusing ${ }^{15} \mathrm{NH}_{4} \mathrm{Cl}$ was to increase the rumen ammonia concentration further. Thus, the ${ }^{15} \mathrm{~N}$ abundance of rumen ammonia was initially higher in steers that had received protein but no urea in the diet (Fig. $3 b$ ) and as ${ }^{15} \mathrm{~N}$ passed rapidly from the rumen ammonia pool into the bacteria this resulted in a higher amount of ${ }^{15} \mathrm{~N}$ labelling of bacteria of these steers in the first hour (Fig. 4). Eventually, however, bacteria from steers given the urea diet became more highly enriched with ${ }^{15} \mathrm{~N}$, presumably as a higher proportion of their 
Table 2. Mean values for free intracellular amino acids and ammonia (umol/g bacterial dry matter) in rumen bacterial samples taken before and at 2, 10,30,90 and $300 \mathrm{~min}$ after ${ }^{15} \mathrm{~N}$ infusion

\begin{tabular}{|c|c|c|c|c|}
\hline \multirow{2}{*}{$\begin{array}{l}\text { Diet*... } \\
\text { Steer no... }\end{array}$} & \multicolumn{2}{|c|}{ Urea } & \multicolumn{2}{|c|}{ DCGM } \\
\hline & C537 & C549 & C537 & C549 \\
\hline Aspartic acid & $1 \cdot 5$ & $1 \cdot 1$ & 1.5 & $3 \cdot 7$ \\
\hline Threonine & $1 \cdot 4$ & $2 \cdot 2$ & 1.7 & 6.9 \\
\hline Serine & $1 \cdot 6$ & $2 \cdot 4$ & $2 \cdot 1$ & $8 \cdot 3$ \\
\hline Glutamine & 0.2 & Trace & 0.0 & 0.0 \\
\hline Glutamic acid & $6 \cdot 7$ & $6 \cdot 3$ & $4 \cdot 8$ & $18 \cdot 4$ \\
\hline Asparagine & 0.0 & 0.0 & 0.0 & 0.0 \\
\hline Proline & 0.9 & 0.6 & $1 \cdot 1$ & $6 \cdot 1$ \\
\hline Glycine & $2 \cdot 9$ & $3 \cdot 2$ & $2 \cdot 8$ & $10 \cdot 5$ \\
\hline Alanine & $7 \cdot 5$ & $11 \cdot 4$ & 8.0 & $23 \cdot 2$ \\
\hline Valine & 1.8 & $3 \cdot 1$ & $2 \cdot 7$ & $8 \cdot 8$ \\
\hline Methionine & $0 \cdot 3$ & 0.7 & $0 \cdot 9$ & $1 \cdot 4$ \\
\hline Cysteine & 0.0 & 0.3 & 0.0 & Trace \\
\hline Isoleucine & 1.0 & $2 \cdot 2$ & 2.0 & 6.8 \\
\hline Leucine & $1 \cdot 4$ & $2 \cdot 8$ & $2 \cdot 4$ & $9 \cdot 3$ \\
\hline Tyrosine & 0.6 & $1 \cdot 0$ & $0 \cdot 3$ & $3 \cdot 2$ \\
\hline Phenylalanine & 0.8 & 1.4 & 0.9 & $3 \cdot 1$ \\
\hline Ammonia & $6 \cdot 8$ & $8 \cdot 3$ & 5.7 & $37 \cdot 0$ \\
\hline Ornithine & Trace & $2 \cdot 0$ & 0.6 & $2 \cdot 7$ \\
\hline Lysine & $2 \cdot 2$ & $4 \cdot 3$ & $2 \cdot 8$ & $11 \cdot 6$ \\
\hline Histidine & 0.2 & 0.2 & Trace & $1 \cdot 0$ \\
\hline Arginine & $0-3$ & 1.4 & 0.5 & $2 \cdot 3$ \\
\hline
\end{tabular}

DCGM, decorticated groundnut meal.

* For details, see Table 1.

Table 3. Variation in ${ }^{15} \mathrm{~N}$ enrichment (atoms $\%$ excess) of bacterial amino acids and intracellular ammonia with time after administration of ${ }^{15} \mathrm{NH}_{4} \mathrm{Cl}$

(Each value is the mean of values for each steer)

\begin{tabular}{|c|c|c|c|c|c|}
\hline \multirow[b]{2}{*}{ Diet $\ddagger$} & \multicolumn{5}{|c|}{ Period after ${ }^{15} \mathrm{~N}$ infusion (min) } \\
\hline & 2 & 10 & 30 & 90 & 300 \\
\hline \multicolumn{6}{|l|}{ Urea } \\
\hline Ammonia & $1 \cdot 36$ & 1.61 & $1 \cdot 24$ & $0.63^{*}$ & $0 \cdot 81$ \\
\hline Alanine & $0 \cdot 70$ & 0.77 & $1 \cdot 16^{*}$ & $1 \cdot 11$ & 0.88 \\
\hline Glutamic acid & $0 \cdot 60$ & 0.79 & $0 \cdot 70^{*}$ & 0.65 & 1.09 \\
\hline Lysine & $0 \cdot 32$ & 0.77 & $0 \cdot 55$ & 0.93 & 0.97 \\
\hline Aspartic acid & $0 \cdot 31$ & 0.47 & $\dagger$ & $0 \cdot 45^{*}$ & $1 \cdot 08$ \\
\hline \multicolumn{6}{|l|}{ DCGM } \\
\hline Ammonia & $2 \cdot 54$ & $2 \cdot 35^{*}$ & $2 \cdot 95$ & 2.09 & 1.62 \\
\hline Alanine & 0.87 & $1 \cdot 40$ & $2 \cdot 12$ & 2.03 & $1 \cdot 62$ \\
\hline Glutamic acid & 0.63 & $1 \cdot 29$ & $2 \cdot 09$ & $2 \cdot 31^{*}$ & 0.95 \\
\hline Aspartic acid & 0.48 & 0.95 & $1 \cdot 59$ & $3.01 *$ & $2 \cdot 33^{*}$ \\
\hline Lysine & 0.38 & 0.58 & $1 \cdot 38$ & $1 \cdot 44$ & $1 \cdot 38$ \\
\hline
\end{tabular}

DCGM, decorticated groundnut meal.

* Only one value.

+ Missing value.

$\ddagger$ For details, see Table 1 . 
protein was produced de novo from $\mathrm{NH}_{3}$, whilst in the presence of DCGM-protein unlabelled products of protein breakdown were also incorporated.

Within the bacteria, label appeared first in protein-free cell supernatant fraction (free intracellular amino acid pool) and then in the bacterial protein both in the intracellular protein and cell wall. The entry of ${ }^{15} \mathrm{~N}$ into the cell wall was slower than into intracellular protein indicating the slower turnover rate of $\mathrm{N}$ in bacterial cell walls. The proportion of label in the intracellular protein and cell walls was higher with the urea diet suggesting that the bacteria were producing more amino acids de novo from the labelled ammonia on this diet. It was also of interest that the proportion of ${ }^{15} \mathrm{~N}$ which remained in the protein-free cell supernatant fraction was greater when the protein-containing diet was given (Fig. 5). This, coupled with the observation that this fraction contained more $\mathrm{N}$ when dietary protein was given and that any ${ }^{15} \mathrm{~N}$-labelled amino acids in this pool would have been utilized for protein synthesis, suggests that bacteria were taking up preformed amino acids (as peptides or free amino acids) in preference to producing amino acids de novo from ammonia. The increased proportion of non-protein ${ }^{15} \mathrm{~N}$ remaining in the intracellular fluid for the DCGM diet compared with the urea diet may have been in the form of ammonia which was not utilized with the same efficiency as by bacteria which did not have a readily available source of preformed amino acids.

The greater net synthesis of bacterial $\mathrm{N}$ compounds in the presence of dietary protein confirms the results of other studies (Hume, 1970; Prins et al. 1979) that preformed units may be required for maximum growth rates. The results were, however, contrary to those reported by Salter et al. (1979) who found little difference in net amounts of bacterial $\mathrm{N}$ synthesized in steers given urea- and DCGM-based diets respectively. It is also possible that if intracellular ammonia were not utilized as efficiently when degradable dietary protein was present, the bacteria selected complete amino acids, possibly as peptides, rather than as $\mathrm{C}$ skeletons to which the amino group was added intracellularly.

The sequence of appearance of the label in the various bacterial fractions was similar with both diets and indicated that ${ }^{15} \mathrm{~N}$ from rumen ammonia first entered the intracellular ammonia pool and was transferred to amino acids from which intracellular and cell wall proteins were synthesized. Of the protein-containing fractions, the more rapid rate of labelling of intracellular protein (precipitated-protein fraction) indicated that its $\mathrm{N}$ turnover rate was greater than that of the cell wall. Of the total free amino acids, alanine was present in the greatest amounts, accounting for $19 \%$ of total amino acid- $\mathrm{N}$ in the protein-free cell supernatant fraction, with glutamate concentration the next highest at $15 \%$. This represents an alanine concentration of $2.36 \mathrm{~mm}$ (assuming that cell water forms $80 \%$ of cell mass), a value which agrees closely with those found by Jenkinson et al. (1979) who also found that alanine was the most abundant free amino acid. Patterns of ${ }^{15} \mathrm{~N}$-labelling of the free amino acid pool showed that in general alanine was labelled at the fastest rate and reached the highest enrichment. The observed rapid incorporation of ${ }^{15} \mathrm{~N}$ into glutamate was not unexpected, since glutamate dehydrogenase is known to be active in rumen bacteria and was thought to be the major pathway of ammonia incorporation (Erfle et al. 1977; Wallace \& Henderson, 1978; Shishkina and Trotsenko, 1979; Smith et al. 1978). However, the appearance of ${ }^{15} \mathrm{~N}$ in alanine at the earliest stages and its high level of enrichment suggest that alanine dehydrogenase $(E C 1.4 .1 .1)$ was extremely active under the conditions of this experiment, confirming the results of Wallace \& Henderson (1978). It should, however, be pointed out that in some experiments alanine accumulation was shown in Bacteriodes amylophilus which contained no detectable alanine dehydrogenase (Jenkinson et al. 1979). Other investigators, using ${ }^{15} \mathrm{~N}$-labelled urea or ammonium chloride to study ammonia incorporation into whole bacteria in vitro, have also found alanine to be one of the most highly labelled amino acids (Shimbayashi et al. 1975; Syvaoja \& Kreula, 1979). Salter 
et al. (1979) found relatively high labelling of alanine in whole bacteria in vivo after adding ${ }^{15} \mathrm{~N}$-labelled urea to the rumen and postulated that this was due to the action of transaminases, the amino group coming from glutamate or aspartate. However, glutamatepyruvate transaminase (EC 2.6.1.2) has not been found in more than low amounts in rumen bacteria (Erfle et al. 1977; Jenkinson et al. 1979) and since levels and rates of enrichment of alanine from the free amino acid fraction in the present study were generally greater than glutamate and always greater than aspartate, its production was probably not a result of transamination.

The production of large amounts of alanine may simply be a means of ammonia fixation. However, reports of alanine excretion from rumen bacteria grown in vitro (Erfle et al. 1977; Stevenson, 1978) suggest that alanine production may be important to the bacteria in some other way. There may be many reasons for this apparent futile synthesis but the three most likely are: (1) as a short-term storage mechanism for ammonia, alanine released into the rumen fluid would be rapidly deaminated back to ammonia and pyruvate, (2) a control mechanism within the bacteria to prevent excess levels of ammonia accumulating, (3) a means of removing excess pyruvate from bacteria when readily available energy is supplied and bacterial metabolism is rapid. Whatever its purpose, alanine dehydrogenase may be of importance in rumen bacteria when soluble carbohydrate and ammonia levels are high.

The authors gratefully acknowledge a studentship from the Agricultural Research Council in support of J.S.B. They thank Dr H. L. Buttle for carrying out the surgical operations, Mrs C. Jones for the care of the steers and Miss P. Marshall for skilled technical assistance.

\section{REFERENCES}

Allison, M. J. (1969). Journal of Animal Science 29, 797-807.

Benson, J. V. Jr, Gordon, M. J. \& Patterson, J. A. (1967). Analytical Biochemistry 18, 228-240.

Blackburn, T. H. \& Hobson, P. N. (1960). Journal of General Microbiology 22, 290-294.

Blackburn, T. H. \& Hullah, W. A. (1974). Canadian Journal of Microbiology 20, 435-441.

Blake, J. S., Salter, D. N. \& Smith, R. H. (1981). Proceedings of the Nutrition Society 40, 3 A.

Byrant, M. P. (1973). Federation Proceedings 32, 1809-1813.

Bryant, M. P. \& Robinson, I. M. (1962). Journal of Bacteriology 84, 605-614.

Burchall, J. J., Reichelt, E. C. \& Wolin, M. J. (1964). Journal of Biological Chemistry 239, $1794-1798$.

Cole, N. A., Johnson, R. R., Owens, F. N. \& Males, J. R. (1976). Journal of Animal Science 43, 497-503.

Erfie, J. D., Sauer, F. D. \& Mahadevan, S. (1977). Journal of Dairy Science 60, $1064-1072$.

Florence, E. \& Milner, D. F. (1979). Analyst, London 104, 378-381.

Goulden, J. D. S. \& Salter, D. N. (1979a). Journal of Chromatography 179, 176-178.

Goulden, J. D. S. \& Salter, D. N. (1979b). Analyst, London 104, 756-765.

Harrison, D. G., Beever, D. E., Thompson, D. J. \& Osbourn, D. F. (1975). Journal of Agricultural Science, Cambridge 85, 93-101.

Hume, I. D. (1970). Australian Journal of Agricultural Research 21, 305-314.

Jenkinson, H. F., Buttery, P. J. \& Lewis, D. (1979). Journal of General Microbiology 113, $305-313$.

Joyner, A. E. \& Baldwin, R. L. (1966). Journal of Bacteriology 92, 1321-1330.

Lewis, D. (1955). British Journal of Nutrition 9, 215-230.

Lloyd-Jones, C. P., Adam, J. S., Hudd, G. A. \& Hill-Cottingham, D. G. (1977). Analyst, London 102, $473-476$.

McDonald, I, W. (1952). Biochemical Journal 51, 86-90.

Mathison, G. W. \& Milligan, L. P. (1971). British Journal of Nutrition 25, 351-366.

Nolan, J. V. \& Leng, R. A. (1972). British Journal of Nutrition 27, 177-194.

Pittman, K. A., Lakshmanans, S. \& Bryant, M. P. (1967). Journal of Bacteriology 93, 1499-1 508.

Prigge, E. C., Galyean, M. L., Owens, F. N., Wagner, D. G. \& Johnson, R. R. (1978). Journal of Animal Science 46, 249-254.

Prins, R. A., Mal-Van Gestal, J. C. \& Counott, G. H. M. (1979). Zeitschrift Tierphysiologie Tierernahrung und Futtermittelkunde 42, 333-339.

Salter, D. N., Daneshvar, K. \& Smith, R. H. (1979). British Journal of Nutrition 41, 197-209.

Salter, D. N. \& Smith, R. H. (1977). British Journal of Nutrition 38, 207-216.

Shimbayashi, K., Obara, Y. \& Yonemura, Y. (1975). Japanese Journal of Zootechnical Science 46, $243-250$. 
Shishkina, V. N. \& Trotsenko, Y. A. (1979). Federation of European Microbiological Societies-Microbiology Letters 5, 187-191.

Smith, C. J., Bryant, M. P. \& Hespell, R. B. (1978). Abstract of the Annual Meeting-American Society of Microbiology 78, K14.

Smith, R. H. (1962). Biochemical Journal 83, 151-163.

Stevenson, I. L. (1978). Canadian Journal of Microbiology 24, 1236-1241.

Sutherland, T. M., Ellis, W. C., Reid, R. S. \& Murray, M. G. (1962). British Journal of Nutrition 16, $603-614$.

Syvaoja, E. L. \& Kreula, M. (1979). Journal of the Scientific Agricultural Society of Finland 51, 497-505.

Wallace, R. J. \& Henderson, C. (1978). Proceedings of the Society for General Microbiology 5, 102 (Abstr).

Warner, A. C. I. (1956). Journal of General Microbiology 28, 129-146. 